\title{
Characterizing the Electrochemical Corrosion Behaviour of a Ni-28wt.\% Al Composite Coating in 3.5\% NaCl Solution
}

\author{
B.I. Onyeachu, ${ }^{a, b}$ X. Peng, ${ }^{a, *}$ E.E. Oguzie, ${ }^{b}$ C.E. Ogukwe ${ }^{b}$ and I. Digbo ${ }^{b}$ \\ ${ }^{a}$ State Key Laboratory for Corrosion and Protection, Institute of Metal Research, \\ Chinese Academy of Science, 62 Wencui Road, Shenyang 110016, China \\ ${ }^{b}$ Electrochemistry and Materials Science Research Laboratory, Department of Chemistry, \\ Federal University of Technology, Owerri, Nigeria
}

Received 24 June 2014; accepted 2 March 2015

\begin{abstract}
The electrochemical corrosion behaviour of an electrodeposited $\mathrm{Ni}-28 \mathrm{wt} . \% \mathrm{Al}$ composite coating was characterized after $24 \mathrm{~h}$ and $72 \mathrm{~h}$ immersion periods in $3.5 \%$ $\mathrm{NaCl}$ solution, using electrochemical and surface probe techniques. Open circuit potential (OCP) and potentiodynamic polarization revealed that the Al particles modify the electrochemical corrosion behaviour of the Ni coating by shifting its $\mathrm{E}_{\mathrm{OCP}}$ more negatively and increasing its anodic dissolution current density, after $24 \mathrm{~h}$ immersion in $3.5 \% \mathrm{NaCl}$ solution. Compared with the Ni coating, the composite can exhibit wellreduced anodic current density and slightly increased cathodic current with immersion up to $72 \mathrm{~h}$. XPS characterization showed that a high rate of water adsorption and rapid formation of a continuous $\mathrm{Ni}(\mathrm{OH})_{2}$ initially occurs on the composite surface which, however, readily thickens during prolonged immersion time and promotes the corrosion product enrichment with $\mathrm{Al}_{2} \mathrm{O}_{3}$. This greatly decreased the rate of corrosion and susceptibility to pitting for the Ni-28wt.\% Al composite after $72 \mathrm{~h}$ immersion in $3.5 \%$ $\mathrm{NaCl}$ solution.
\end{abstract}

Keywords: Composite, corrosion resistance, $\mathrm{XPS}, \mathrm{Al}_{2} \mathrm{O}_{3}$, immersion.

\section{Introduction}

Electrodeposited $\mathrm{Ni}$ coatings have been greatly employed in many fields to improve the surface finishing, wear properties and corrosion resistance of many metallic substrates. The characterization of the electrochemical corrosion behaviour of pure Ni coatings has been undertaken in neutral, alkaline and acidic

\footnotetext{
* Corresponding author. E-mail address: xpeng@imr.ac.cn
} 
corrosion environments using potentiodynamic polarization and X-ray photoelectron spectroscopy [1].

Co-electrodeposition of Ni coatings with micron or sub-micron size particles would yield Ni matrix composite coatings with better mechanical [2-4] and electrochemical properties [5-7] than pure Ni coatings. A high content of the reinforcement particles is usually important for improving the $\mathrm{Ni}$ coating properties. Co-electrodeposition of $\mathrm{Ni}$ coatings with $\mathrm{Al}$ particles will yield $\mathrm{Ni}-\mathrm{Al}$ composite coatings. In dry corrosion environments, electrodeposited $\mathrm{Ni}$ containing up to $28 \mathrm{wt} . \%$ of $\mathrm{Al}$ particles exhibited greater oxidation resistance than pure Ni coating, because of the ability to enrich the NiO scale with a slowgrowing, thermodynamically stable and highly resistant $\mathrm{Al}_{2} \mathrm{O}_{3}$ scale [8]. With subsequent vacuum annealing treatment, the $\mathrm{Ni}$ grains and $\mathrm{Al}$ particles in the $\mathrm{Ni}-$ $\mathrm{Al}$ composite can react to form $\gamma-\mathrm{Ni}_{3} \mathrm{Al}$ intermetallic compounds in a resultant ultra-fine grain alloy coating which exhibits greater oxidation resistance and better oxide scale formation mechanism, compared with a conventional coarse grain $\gamma^{\prime}-\mathrm{Ni}_{3} \mathrm{Al}$ alloy [9].

Unfortunately, however, reports on the characterization of the electrochemical corrosion behaviour of $\mathrm{Ni}-\mathrm{Al}$ composite coatings are still lacking in the literature, thus, limiting the application of the $\mathrm{Ni}-\mathrm{Al}$ composite coatings in wet environments. During the Ni corrosion it is envisaged that $\mathrm{Al}$ particles content up to 28 wt. $\%$ may replicate the oxidation behaviour of the $\mathrm{Ni}-\mathrm{Al}$ composite provided that the Al particles can participate actively in the electrochemical process and enrich the $\mathrm{Ni}$ corrosion product with the more resistant $\mathrm{Al}_{2} \mathrm{O}_{3}$; characterized by low solubility and conductivity, at least, in the $\mathrm{Al}_{2} \mathrm{O}_{3}$-stability $\mathrm{pH}$ range of 4-9 [10]. Such should be a veritable means to further improve the electrochemical corrosion behaviour of the pure Ni coating.

In the present work, we electrodeposited a $\mathrm{Ni}-28 \mathrm{wt} . \% \mathrm{Al}$ composite coating on $\mathrm{Ni}$ substrates and, thereafter, characterized its electrochemical corrosion behaviour in $3.5 \% \mathrm{NaCl}$ solution, compared with a pure $\mathrm{Ni}$ coating fabricated from the same bath without $\mathrm{Al}$ particles. We focus on the effect of exposure time, after $24 \mathrm{~h}$ and $72 \mathrm{~h}$, on the enrichment of the Ni corrosion product with the protective $\mathrm{Al}_{2} \mathrm{O}_{3}$.

\section{Experimental \\ Materials preparation}

All reagents were analytical grade, used as source without further purification. Deionized water was used for all solution preparation. Pure $\mathrm{Ni}$ coupons (99.99\%), with dimensions $12 \times 10 \times 2 \mathrm{~mm}^{3}$, were used as the substrate upon which the pure $\mathrm{Ni}$ and $\mathrm{Ni}-\mathrm{Al}$ composite coatings were electrodeposited. The substrates were prepared by mechanically abrading to final 800 mesh size using $\mathrm{Si}-\mathrm{C}$ grit paper, washed with distilled water, ultrasonically cleaned in acetone to remove any form of adherent particles from the surface, and dried with a mechanical drier. Electrodeposition of the pure Ni coatings was performed at 2 $\mathrm{A} / \mathrm{dm}^{2}$ current density from a Ni-sulphate bath containing $150 \mathrm{~g} / \mathrm{L} \mathrm{NiSO}_{4} \cdot 6 \mathrm{H}_{2} \mathrm{O}$, $\left.5 \mathrm{~g} / \mathrm{L} \quad \mathrm{NH}_{4} \mathrm{Cl}, 15 \mathrm{~g} / \mathrm{L} \quad \mathrm{H}_{3} \mathrm{BO}_{3}, 0.1 \mathrm{~g} / \mathrm{L} \quad \mathrm{C}_{12} \mathrm{H}_{25} \mathrm{Na}-\mathrm{SO}_{4}\right)$. The $\mathrm{Ni}-28 w t . \% \mathrm{Al}$ 
composite coatings were fabricated at the same current density by introducing appropriate amount of $1 \mu \mathrm{m}$-size $\mathrm{Al}$ particles into the Ni-sulphate bath [9]. After each deposition, coatings were rinsed with distilled water, ultrasonically cleaned in acetone, and oven-dried at $105{ }^{\circ} \mathrm{C}$ for $2 \mathrm{~h}$.

\section{Surface feature and corrosion product characterization}

The surface morphology of the pure $\mathrm{Ni}$ and $\mathrm{Ni}-28 \mathrm{wt} . \% \mathrm{Al}$ composite coatings was probed in the as-deposited state and after $72 \mathrm{~h}$ immersion without and with subsequent polarization, using a scanning electron microscope (SEM) (FEIInspect/OXFORDINSTRUMENTS-X-Max), hyphenated with an energy dispersive X-ray (EDAX) spectrophotometer employed for the elemental composition analysis. The corrosion products formed by pure $\mathrm{Ni}$ and $\mathrm{Ni}-$ 28wt.\%Al composite coatings were characterized: (i) as-polarized after $24 \mathrm{~h}$ immersion and (ii) after $72 \mathrm{~h}$ immersion without and with subsequent polarization, by X-ray photoelectron spectroscopy (XPS) using XPS-ESCALAB 250 Thermo VG X-ray spectrometer with monochromatic $\mathrm{AlK}_{\alpha}(1486.6 \mathrm{eV})$ radiation source at a pass energy of $1 \mathrm{keV}$ and sputtering rate $0.04 \mathrm{~nm} / \mathrm{s}$ on a sample area of $2 \mathrm{~mm} \mathrm{X} 2 \mathrm{~mm}$. Sputtering was performed for 0, 50 and $200 \mathrm{~s}$. Spectra peak deconvolution of the $\mathrm{Ni} 2 \mathrm{p}_{3 / 2}, \mathrm{Al} 2 \mathrm{p}_{3 / 2}$ and $\mathrm{O} 1 \mathrm{~s}$ peaks was performed with the aid of XPSPEAK4.1 processing software (Chemistry Ltd., CUHK) in the Shirley background after calibrating with the C 1s peak at 284.6 $\mathrm{eV}$. Considering that the surface of the corrosion product layer, i.e., at $0 \mathrm{~s}$ sputtering, should contain much impurities and may not provide accurate analytical information during the characterization, the corrosion products detected by XPS after $50 \mathrm{~s}(\sim 2 \mathrm{~nm}$ depth, and regarded henceforth as "outer layer" of the corrosion product) and $200 \mathrm{~s}(\sim 8 \mathrm{~nm}$ depth, regarded as "inner layer" of the corrosion product) were, therefore, analysed to understand the chemistry of formation and transformation of the corrosion products in relation to the depth changes of the layer. The peaks of $\mathrm{Al} 2 \mathrm{p}_{3 / 2}, \mathrm{Ni} 2 \mathrm{p}_{3 / 2}$ and $\mathrm{O} 1 \mathrm{~s}$ acquired after $50 \mathrm{~s}$ and $200 \mathrm{~s}$ sputtering were, therefore, deconvoluted for the corresponding corrosion products. The volume percentage of the total oxide and hydroxide species, and hence the contribution of each phase to the corrosion product, was calculated on the basis of the $\mathrm{O}^{2-}$ and $\mathrm{OH}^{-}$peak area with respect to the sum of peak areas of the O 1s, Eq. (1). Subsequently, the volume percentage of $\mathrm{Ni} / \mathrm{Al}$-oxide (or hydroxide) was calculated on the basis of the $\mathrm{Ni} / \mathrm{Al}$ peak area in $\mathrm{O}^{2-}$ or $\mathrm{OH}^{-}$phase to the volume percentage of $\mathrm{O}^{2-}$ or $\mathrm{OH}^{-}$respectively, Eqs. (2) and (3).

$$
\%\left(\mathrm{O}^{2-} / \mathrm{OH}^{-}\right)=\frac{\text { Peak area of }\left(\mathrm{O}^{2-} / \mathrm{OH}^{-}\right)}{\text {Total peak area of O 1s }} \times 100
$$

$$
\%(\mathrm{Ni} / \mathrm{Al}-\text { oxide })=\frac{\text { Peak area }(\mathrm{Ni} / \mathrm{Al}-\text { oxide })}{\text { Sum of peak areas }(\mathrm{Ni} / \mathrm{Al}-\text { oxide })} \quad \%\left(\mathrm{O}^{2-}\right)
$$




$$
\%(\mathrm{Ni} / \mathrm{Al} \text {-hydroxide })=\frac{\text { Peak area }(\mathrm{Ni} / \mathrm{Al} \text {-hydroxide })}{\text { Sum of peak areas }(\mathrm{Ni} / \mathrm{Al} \text {-hydroxide })} \quad . \%\left(\mathrm{OH}^{-}\right)
$$

\section{Electrochemical characterization}

The electrochemical corrosion behaviour of the $\mathrm{Ni}$ and $\mathrm{Ni}-28 \mathrm{wt} . \% \mathrm{Al}$ composite coatings was characterized by open circuit potential $\left(\mathrm{E}_{\mathrm{OCP}}\right)$ and potentiodynamic polarization technique using a PARSTAT 273A Potentiostat/Galvanostat (Princeton Applied Research), after immersing the coating samples for $24 \mathrm{~h}$ and $72 \mathrm{~h}$ in $3.5 \% \mathrm{NaCl}$ solution. The coatings (used as working electrodes) were prepared by embedding in a mixture of rosin and paraffin to expose an area of 1 $\mathrm{cm}^{2}$ for the electrochemical reaction. A saturated calomel electrode (SCE), connected via a Luggin capillary, was employed as reference electrode, while a platinum sheet was the counter electrode. The coatings were polarized, after being allowed to reach an open circuit potential $\left(\mathrm{E}_{\mathrm{OCP}}\right)$, in the potential range of $0.25 \mathrm{~V} / \mathrm{E}_{\mathrm{OCP}}$ to $+0.25 \mathrm{~V} / \mathrm{SCE}$.

\section{Results \\ Surface morphology of Ni coating and Ni-Al composite}

The SEM morphologies in Fig. 1 reveal the surfaces of the electrodeposited pure $\mathrm{Ni}$ coating and $\mathrm{Ni}-28 \mathrm{wt}$.\%Al composite fabricated from the Ni sulphate bath. The surface of the pure Ni coating, Fig. 1(a), is characterized by large Ni grains with blocky microstructures. The reinforcement of the $\mathrm{Ni}$ coating with $\mathrm{Al}$ particles obviously modified the size and morphology of the $\mathrm{Ni}$ surface grains in the Ni-28wt.\%Al composite, Fig. 1(b). Thus, the electrodeposition of the pure Ni coating from the $\mathrm{Ni}$ sulphate bath follows a grain growth mechanism, whereas the Al particles promote the nucleation mechanism. Therefore, the Al particles provide excess of sites on the substrate for the electro-reduction and nucleation of the $\mathrm{Ni}$ grains during the electrodeposition.

\section{Open circuit potential measurements}

The plots of potential versus time for the attainment of open circuit potential $\left(\mathrm{E}_{\mathrm{OCP}}\right)$ for the pure $\mathrm{Ni}$ and the $\mathrm{Ni}-28 \mathrm{wt} . \% \mathrm{Al}$ composite coatings are provided in Fig. 2. The coatings exhibited stable $\mathrm{E}_{\mathrm{OCP}}$ values throughout the potential-time scan for both immersion times, which indicates that the coatings can form stable corrosion product layers during the immersion in the $3.5 \% \mathrm{NaCl}$ solution. However, the $\mathrm{E}_{\mathrm{OCP}}$ value was largely more negative for the composite after the $24 \mathrm{~h}$ immersion, Fig. 2(a), but increased to a value more positive than for the pure Ni coating after $72 \mathrm{~h}$ immersion in $3.5 \% \mathrm{NaCl}$ solution, Fig. 2(b). This implies that the surface of the $\mathrm{Ni}-28 \mathrm{wt} . \% \mathrm{Al}$ composite became greatly less susceptible to the electrochemical processes during this longer immersion time. 
(a)

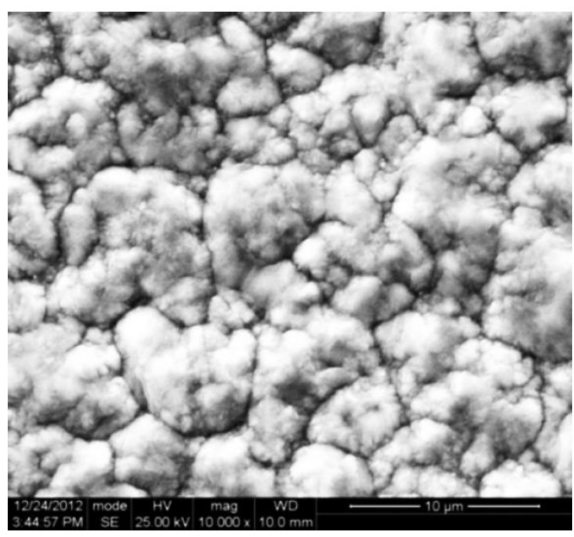

(b)

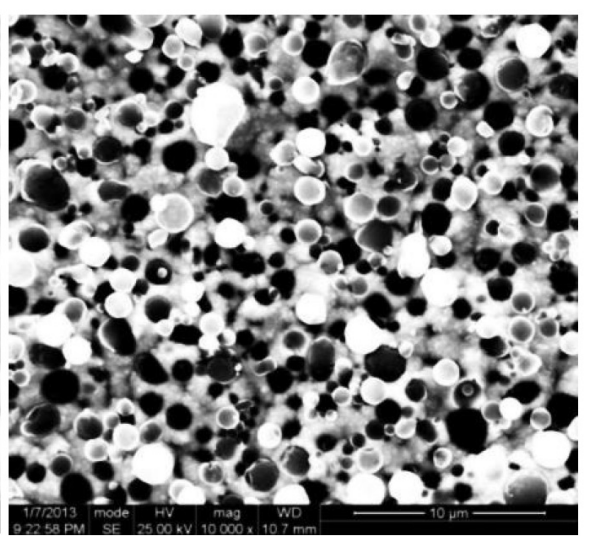

Figure 1. SEM surface micrographs of (a) pure Ni coating, and (b) Ni-28wt.\%Al composite, electrodeposited from the $\mathrm{NiSO}_{4}$ bath at $\mathrm{pH}=5$.
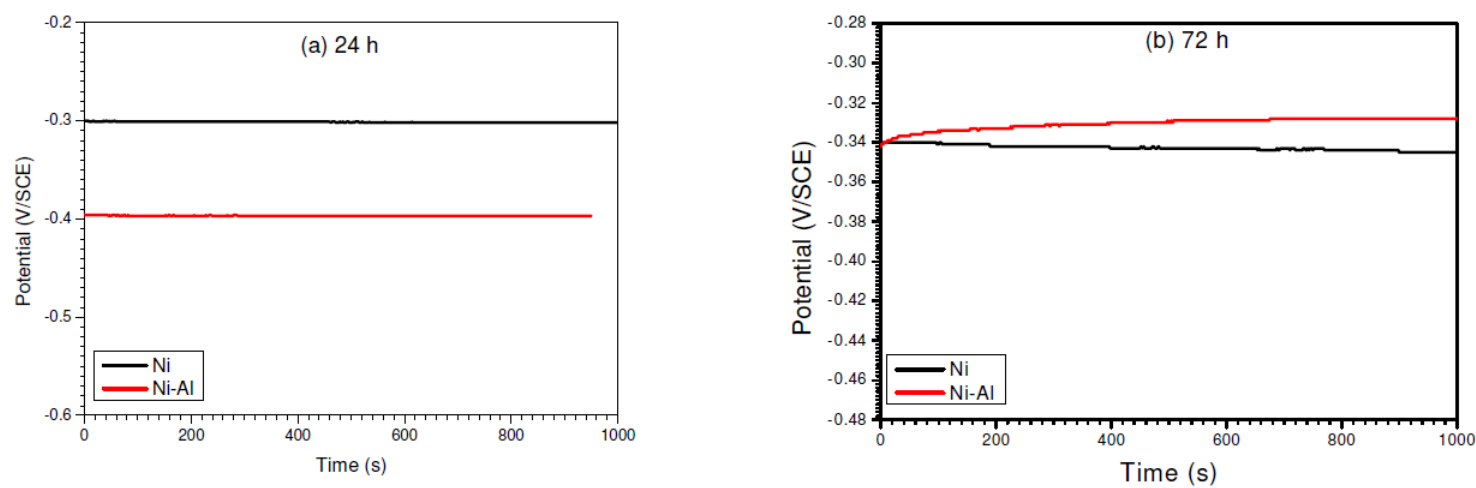

Figure 2. Open circuit potential measurement for $\mathrm{Ni}$ and $\mathrm{Ni}-28 \mathrm{wt} . \% \mathrm{Al}$ composite after immersion in $3.5 \% \mathrm{NaCl}$ solution for (a) $24 \mathrm{~h}$ and (b) $72 \mathrm{~h}$ immersion period.

\section{Potentiodynamic polarization measurement}

The potentiodynamic polarization curves for the pure $\mathrm{Ni}$ coating and the $\mathrm{Ni}-$ $28 \mathrm{wt} . \% \mathrm{Al}$ composite, after $24 \mathrm{~h}$ and $72 \mathrm{~h}$ immersion in the $3.5 \% \mathrm{NaCl}$ solution, are provided in Fig. 3. The composite coating exhibited slightly higher cathodic current density throughout the polarization, compared with the pure Ni coating. However, while the anodic current density (which is usually related to the coating dissolution) was largely greater for the polarized composite coating after $24 \mathrm{~h}$ immersion, the anodic current density was greatly lower than for the pure $\mathrm{Ni}$ coating, after $72 \mathrm{~h}$ immersion in $3.5 \% \mathrm{NaCl}$ solution (see Table 1). This is consistent with the observed increase in the $\mathrm{E}_{\mathrm{OCP}}$ for the composite after $72 \mathrm{~h}$ immersion, and indicates the formation of a very stable and protective corrosion product layer during the polarization of the $\mathrm{Ni}-28 \mathrm{wt} . \% \mathrm{Al}$ composite coating after this longer immersion time in the $3.5 \% \mathrm{NaCl}$ solution, while the corrosion product layer on the pure Ni surface became more degraded.

\section{Corrosion product characterization}

The polarization results showed that the $\mathrm{Ni}-28 \mathrm{wt} . \% \mathrm{Al}$ composite displayed greatly reduced anodic current density, i.e., reduced corrosion rate after the $72 \mathrm{~h}$ immersion in the $3.5 \% \mathrm{NaCl}$ solution. Thus, the surface of the composite was characterized using X-ray photoelectron spectroscopy (XPS) to analyse the 
chemistry of the corrosion product formation and transformation. After sputtering for 0,50 and $200 \mathrm{~s}$ in the binding energy range of $0-1200 \mathrm{eV}$ at 0.04 $\mathrm{nm} / \mathrm{s}$, XPS detected the following peaks with corresponding binding energy ranges: Ni 2p (852-861 eV), Al 2p (72.9-75.7 eV) and O 1s (529-533 eV). The corresponding spectra are presented for $24 \mathrm{~h}$ immersion with subsequent polarization, Fig. 4(a), for $72 \mathrm{~h}$ immersion before polarization, Fig. 5(a), and for $72 \mathrm{~h}$ immersion with subsequent polarization, Fig. 6(a). XPS detection of Al 2p and $\mathrm{Ni} 2 \mathrm{p}$ peaks confirms the contributions of $\mathrm{Al}$ and $\mathrm{Ni}$ compounds in the corrosion product layer. The O1s peaks were detected around 529.7-530.4 eV, $530.8-531.4 \mathrm{eV}$ and 532.2-532.4 eV and were attributed to the presence of oxides, hydroxides and adsorbed water molecules, respectively. The composition of the total oxide or hydroxide compounds, and hence the contribution of each phase to the corrosion product, as calculated from Eqs. (1-3), is presented in Table 2.
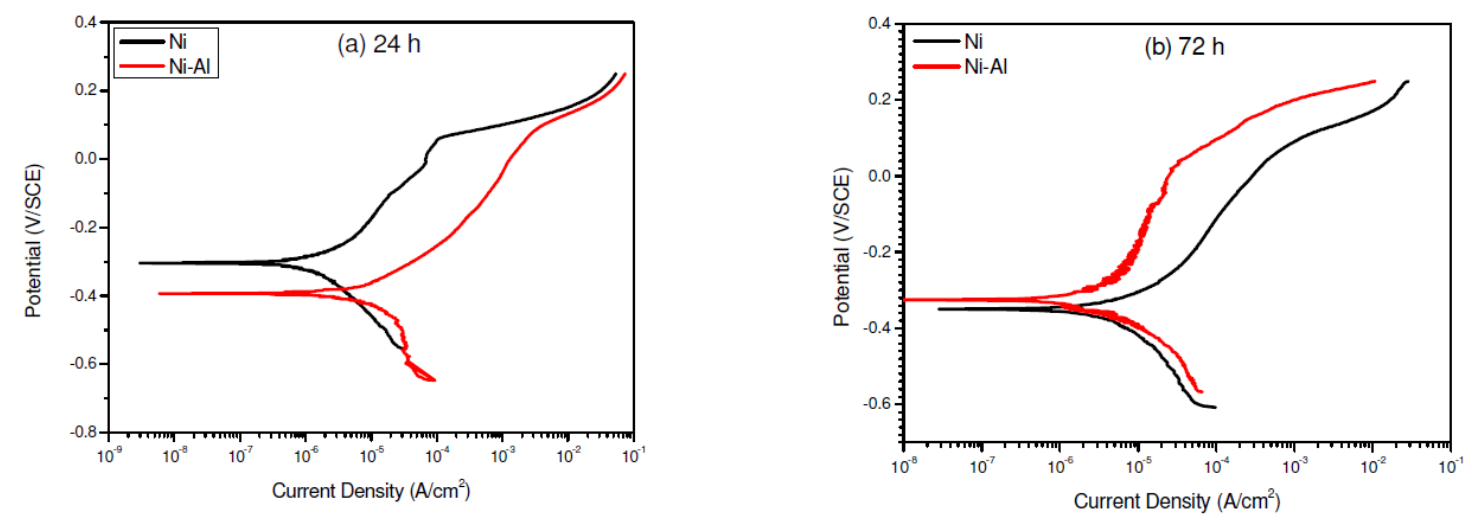

Figure 3. Potentiodynamic polarization curves for $\mathrm{Ni}$ and $\mathrm{Ni}-28 \mathrm{wt} . \% \mathrm{Al}$ composite after $24 \mathrm{~h}$ and $72 \mathrm{~h}$ immersion in $3.5 \% \mathrm{NaCl}$ solution.

Table 1. Polarization parameters for $\mathrm{Ni}$ coating and $\mathrm{Ni}-28 \mathrm{wt} . \% \mathrm{Al}$ composite after 24 and $72 \mathrm{~h}$ immersion in $3.5 \% \mathrm{NaCl}$ solution.

\begin{tabular}{lllllll}
\hline & \multicolumn{2}{c}{$\mathrm{t}=24 \mathrm{~h}$ immersion } & & \multicolumn{2}{c}{$\mathrm{t}=72 \mathrm{~h}$ immersion } \\
\cline { 2 - 3 } & $\mathrm{Ni}$ & $\mathrm{Ni}-\mathrm{Al}$ & & $\mathrm{Ni}$ & $\mathrm{Ni}-\mathrm{Al}$ \\
\hline $\mathbf{E}_{\text {corr }}(\mathbf{m V} / \mathbf{S C E})$ & -303 & -393 & & & -350 & -325 \\
$\mathbf{I}_{\text {corr }}\left(\boldsymbol{\mu} \mathbf{A} / \mathbf{c m}^{2}\right)$ & 2.226 & 7.648 & & & 6.571 & 2.966 \\
$\boldsymbol{\beta}_{\mathbf{a}}(\mathbf{m V} / \mathbf{d e c})$ & 185 & 122 & & 149 & 212 \\
$\boldsymbol{\beta}_{\mathbf{c}}(\mathbf{m V} / \mathbf{d e c})$ & 273 & 167 & & 243 & 127 \\
\hline
\end{tabular}

Based on the result in Table 2, the surface of the Ni-28wt.\%Al composite after $24 \mathrm{~h}$ immersion with subsequent polarization contains largely adsorbed water molecules, making up $69 \%$ and $48 \%$ on the outer and in the inner layers, respectively. The major corrosion product formed in the entire layer was $\mathrm{Ni}(\mathrm{OH})_{2}$ ( $\mathrm{Ni} 2 \mathrm{p}_{3 / 2}$ binding energy at $856.6 \mathrm{eV}$ [11]). Only $5 \%$ of $\mathrm{Al}_{2} \mathrm{O}_{3}\left(\mathrm{Al} 2 \mathrm{p}_{3 / 2}\right.$ binding energy at $74.5 \mathrm{eV}$ [12]) was detected on the outer layer, while the composition slightly increased to $7 \%$ in the inner layer. An Al 2 $\mathrm{p}_{3 / 2}$ peak (3\%) was detected at $73.8 \mathrm{eV}$ in the inner layer and was also attributed to the formation of $\mathrm{Al}_{2} \mathrm{O}_{3}$ [12]. 
(a)

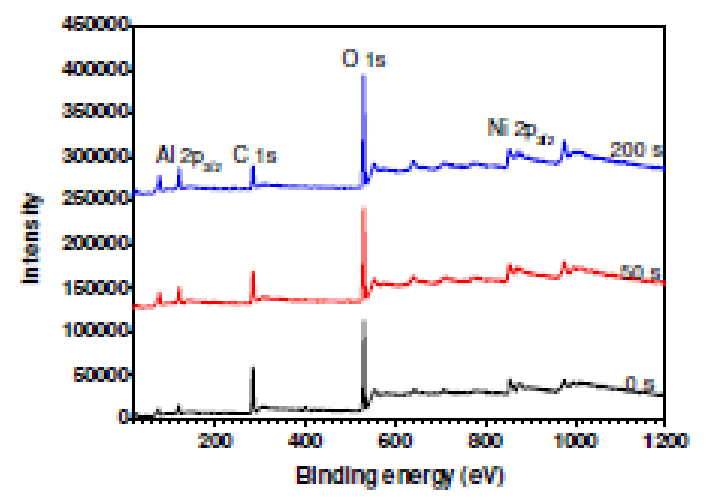

(b)
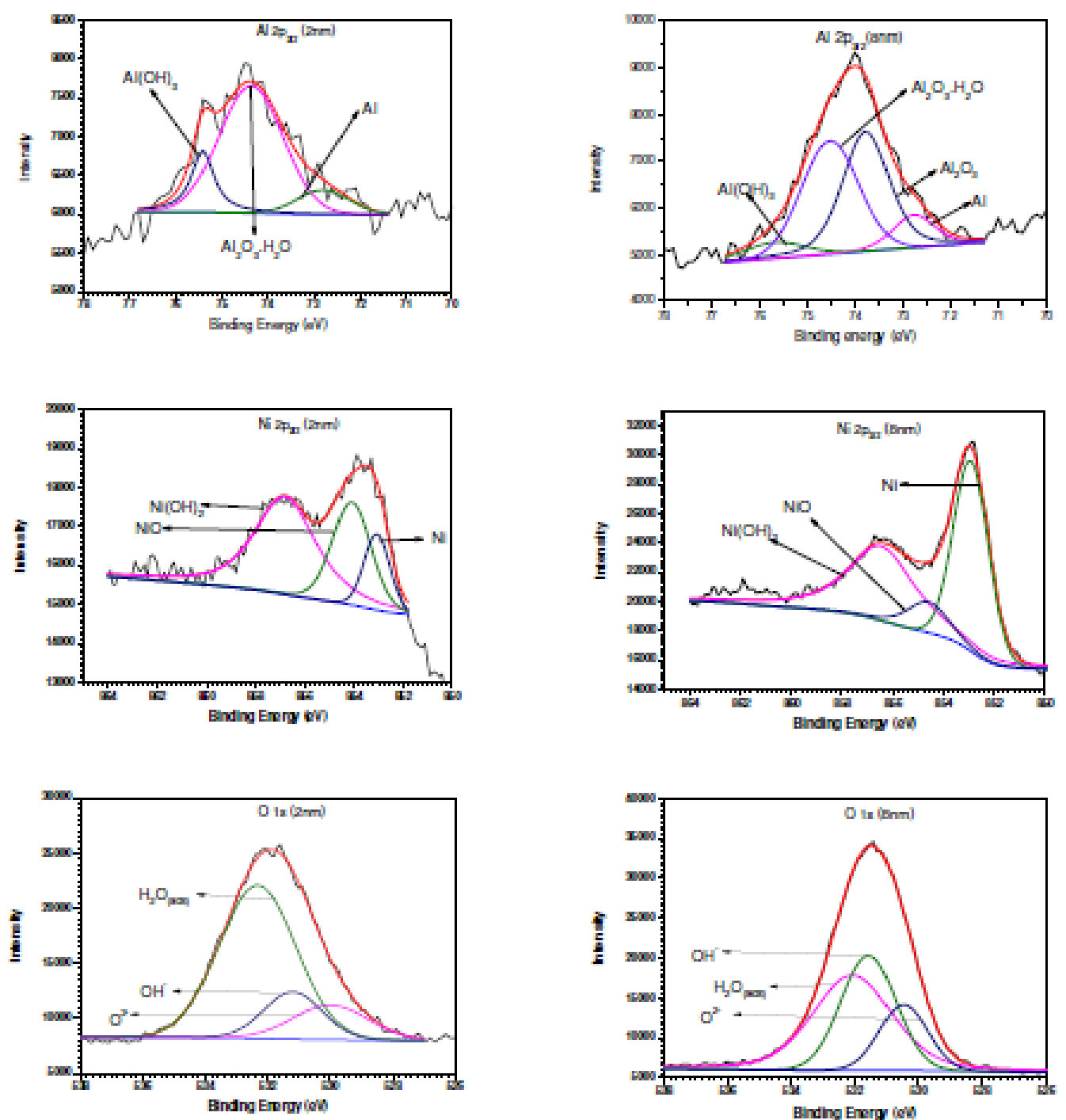

Figure 4. (a) XPS spectrum acquired after different time of sputtering for $\mathrm{Ni}-28 \mathrm{wt} . \% \mathrm{Al}$ composite in $3.5 \% \mathrm{NaCl}$ solution after $24 \mathrm{~h}$ immersion with subsequent polarization, and (b) deconvolution of the $\mathrm{Ni} 2 \mathrm{p}_{3 / 2}, \mathrm{Al} 2 \mathrm{p}_{3 / 2}$ and $\mathrm{O} 1 \mathrm{~s}$ spectra acquired after $50 \mathrm{~s}$ and $200 \mathrm{~s}$ sputtering. 
(a)

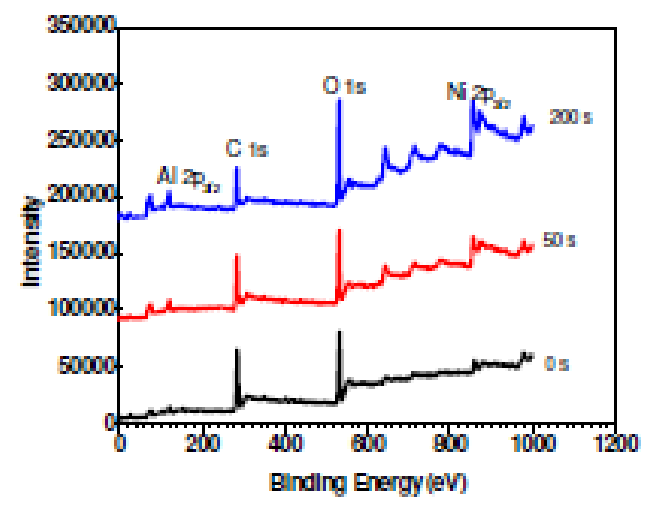

(b)
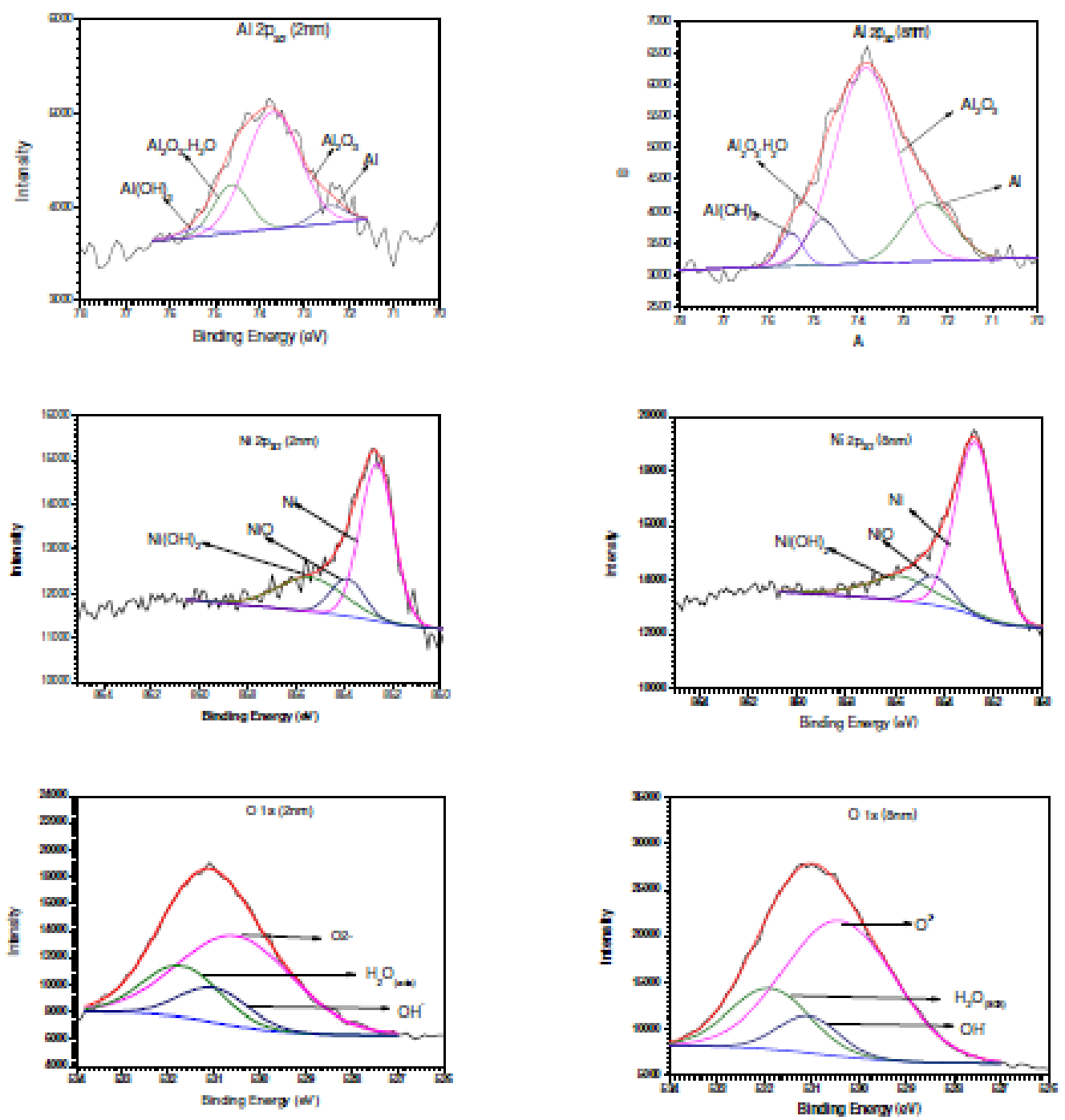

Figure 5. (a) XPS spectrum acquired for $\mathrm{Ni}-28 \mathrm{wt} . \% \mathrm{Al}$ composite in $3.5 \% \mathrm{NaCl}$ solution after $72 \mathrm{~h}$ immersion without polarization, and (b) deconvolution of the $\mathrm{Ni}$ $2 \mathrm{p}_{3 / 2}, \mathrm{Al} 2 \mathrm{p}_{3 / 2}$ and $\mathrm{O} 1 \mathrm{~s}$ spectra acquired after $50 \mathrm{~s}$ and $200 \mathrm{~s}$ sputtering. 
(a)

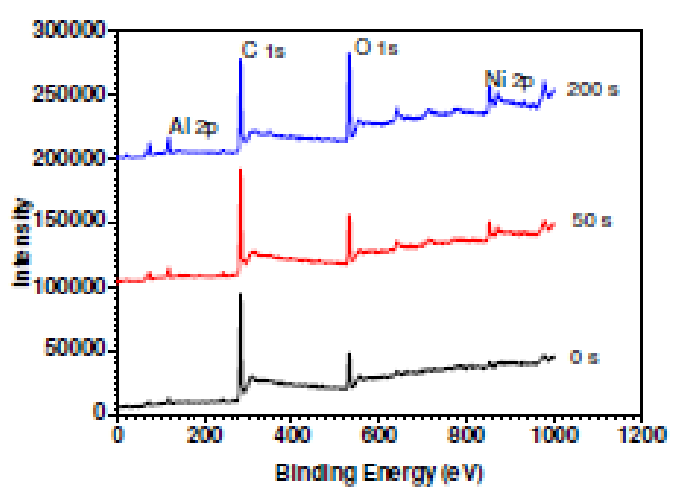

(b)
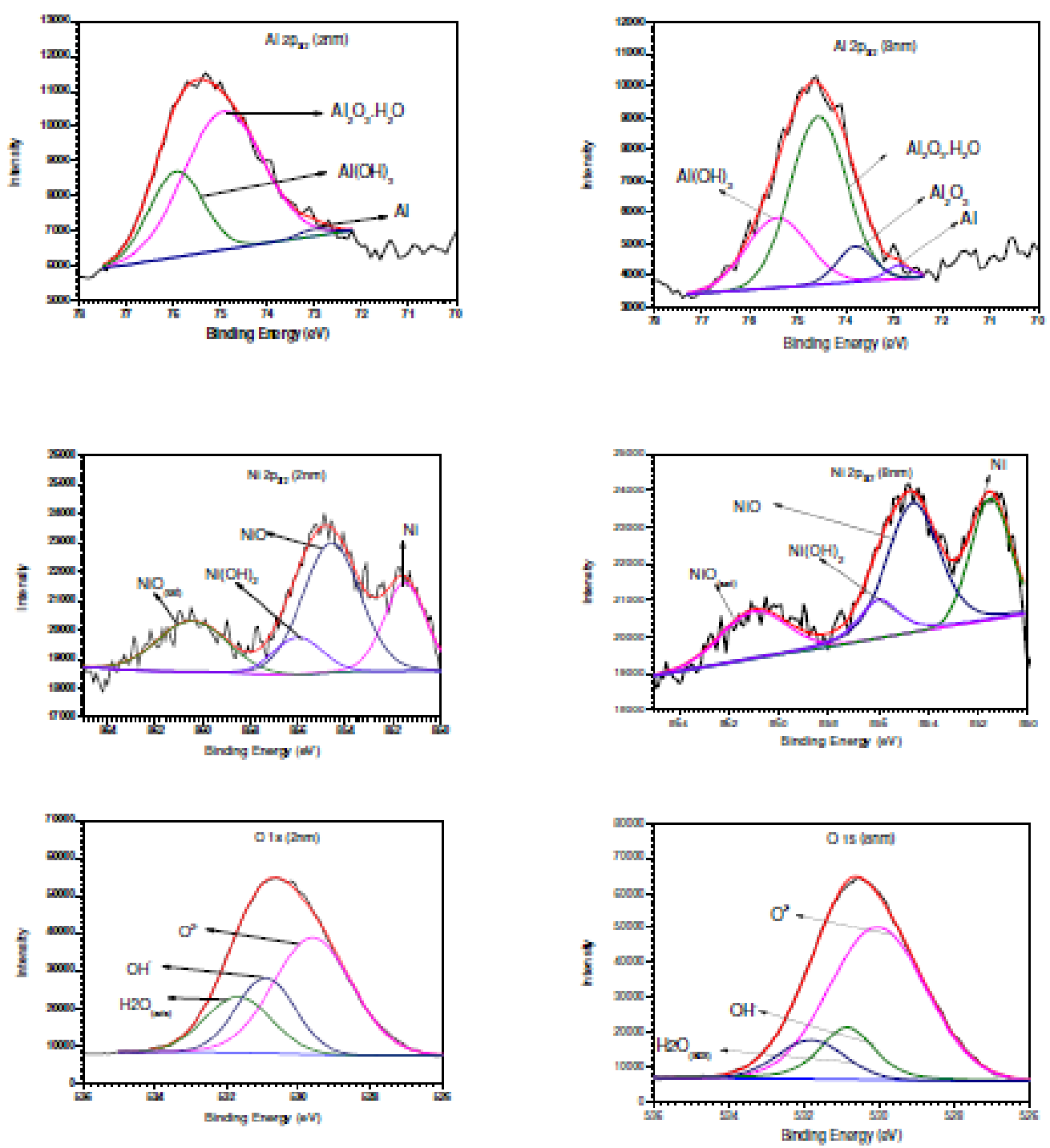

Figure 6. (a) XPS spectrum acquired for $\mathrm{Ni}-28 \mathrm{wt} . \% \mathrm{Al}$ composite in $3.5 \% \mathrm{NaCl}$ solution after $72 \mathrm{~h}$ immersion with subsequent polarization, and (b) deconvolution of the $\mathrm{Ni} 2 \mathrm{p}_{3 / 2}, \mathrm{Al} 2 \mathrm{p}_{3 / 2}$ and $\mathrm{O} 1 \mathrm{~s}$ spectra acquired after $50 \mathrm{~s}$ and $200 \mathrm{~s}$ sputtering. 
Table 2. Percentage composition of the corrosion products formed by the Ni-28wt.\% Al composite in $3.5 \% \mathrm{NaCl}$ solution obtained after $50 \mathrm{~s}$ and $200 \mathrm{~s}$ sputtering, for $24 \mathrm{~h}$ immersion with subsequent polarization and for $72 \mathrm{~h}$ immersion without and with subsequent polarization.

\begin{tabular}{|c|c|c|c|c|}
\hline \multirow{7}{*}{$\begin{array}{c}24 \mathrm{~h} \\
\text { (polarization) }\end{array}$} & \multicolumn{2}{|c|}{$2 \mathrm{~nm}$} & \multicolumn{2}{|c|}{$8 \mathrm{~nm}$} \\
\hline & $\mathrm{N} 2 \mathrm{p}_{3 / 2}$ & $\mathrm{Al} 2 \mathrm{p}_{3 / 2}$ & $\mathrm{~N} 2 \mathrm{p}_{3 / 2}$ & $\mathrm{Al} 2 \mathrm{p}_{3 / 2}$ \\
\hline & \multicolumn{2}{|c|}{$\mathrm{O}^{2-}(15 \%)$} & \multicolumn{2}{|c|}{$\mathrm{O}^{2-}(17 \%)$} \\
\hline & \multirow[t]{2}{*}{$\mathrm{NiO}(10 \%)$} & \multirow[t]{2}{*}{$\mathrm{Al}_{2} \mathrm{O}_{3} \cdot \mathrm{H}_{2} \mathrm{O}(5 \%)$} & \multirow[t]{2}{*}{$\mathrm{NiO}(7 \%)$} & $\mathrm{Al}_{2} \mathrm{O}_{3}(5 \%)$ \\
\hline & & & & $\mathrm{Al}_{2} \mathrm{O}_{3} \cdot \mathrm{H}_{2} \mathrm{O}(5 \%)$ \\
\hline & \multicolumn{2}{|c|}{$\mathrm{OH}^{-}(16 \%)$} & \multicolumn{2}{|c|}{$\mathrm{OH}^{-}(35 \%)$} \\
\hline & $\mathrm{Ni}(\mathrm{OH})_{2}(15 \%)$ & $\mathrm{Al}(\mathrm{OH})_{3}(1 \%)$ & $\mathrm{Ni}(\mathrm{OH})_{2}(34 \%)$ & $\mathrm{Al}(\mathrm{OH})_{3}(1 \%)$ \\
\hline \multirow{6}{*}{$\begin{array}{c}72 \mathrm{~h} \\
\text { (polarization) }\end{array}$} & & & & \\
\hline & \multicolumn{2}{|c|}{$\mathrm{O}^{2-}(54 \%)$} & \multicolumn{2}{|c|}{$\mathrm{O}^{2-}(71 \%)$} \\
\hline & \multirow[t]{2}{*}{$\mathrm{NiO}(34 \%)$} & \multirow{2}{*}{$\mathrm{Al}_{2} \mathrm{O}_{3} \cdot \mathrm{H}_{2} \mathrm{O}(20 \%)$} & \multirow[t]{2}{*}{$\mathrm{NiO}(38 \%)$} & $\mathrm{Al}_{2} \mathrm{O}_{3}(4 \%)$ \\
\hline & & & & $\mathrm{Al}_{2} \mathrm{O}_{3} \cdot \mathrm{H}_{2} \mathrm{O}(29 \%)$ \\
\hline & \multicolumn{2}{|c|}{$\mathrm{OH}^{-}(25 \%)$} & \multicolumn{2}{|c|}{$\mathrm{OH}^{-}(16 \%)$} \\
\hline & $\mathrm{Ni}(\mathrm{OH})_{2}(12 \%)$ & $\mathrm{Al}(\mathrm{OH})_{3}(13 \%)$ & $\mathrm{Ni}(\mathrm{OH})_{2}(7 \%)$ & $\mathrm{Al}(\mathrm{OH})_{3}(9 \%)$ \\
\hline \multirow{6}{*}{$\begin{array}{c}72 \mathrm{~h} \\
\text { (no polarization) }\end{array}$} & & & & \\
\hline & \multicolumn{2}{|c|}{$\mathrm{O}^{2-}(62 \%)$} & \multicolumn{2}{|c|}{$\mathrm{O}^{2-}(68 \%)$} \\
\hline & \multirow[t]{2}{*}{$\mathrm{NiO}(23 \%)$} & $\mathrm{Al}_{2} \mathrm{O}_{3}(31 \%)$ & \multirow[t]{2}{*}{$\mathrm{NiO}(16 \%)$} & $\mathrm{Al}_{2} \mathrm{O}_{3}(46 \%)$ \\
\hline & & $\mathrm{Al}_{2} \mathrm{O}_{3} \cdot \mathrm{H}_{2} \mathrm{O}(8 \%)$ & & $\mathrm{Al}_{2} \mathrm{O}_{3} \cdot \mathrm{H}_{2} \mathrm{O}(6 \%)$ \\
\hline & \multicolumn{2}{|c|}{$\mathrm{OH}^{-}(14 \%)$} & \multicolumn{2}{|c|}{$\mathrm{OH}_{(531.1 \mathrm{eV})}(10 \%)$} \\
\hline & $\mathrm{Ni}(\mathrm{OH})_{2}(13 \%)$ & $\mathrm{Al}(\mathrm{OH})_{3}(1 \%)$ & $\mathrm{Ni}(\mathrm{OH})_{2}(9 \%)$ & $\mathrm{Al}(\mathrm{OH})_{3}(1 \%)$ \\
\hline
\end{tabular}

The composition of $\mathrm{NiO}$ (854 eV [11]) decreased with the depth of the corrosion product layer. Before polarizing the $\mathrm{Ni}-\mathrm{Al}$ composite after $72 \mathrm{~h}$ immersion in $3.5 \% \mathrm{NaCl}$ solution, XPS detected $62 \%$ and $68 \%$ of oxide compounds in the outer and inner layers, respectively. The total composition of the $\mathrm{Al}_{2} \mathrm{O}_{3}$ compounds at $74.5 \mathrm{eV}$ (9\%; outer layer and 6\%; inner layer) and $73.8 \mathrm{eV}$ (30\%; outer layer and $46 \%$; inner layer) was greatly larger than the total composition of the $\mathrm{NiO}$ in the oxide phase, and the $\mathrm{Ni}(\mathrm{OH})_{2}$ composition was as low as $13 \%$ and $9 \%$ in the outer and inner layer, respectively. When polarized, after the $72 \mathrm{~h}$ immersion in $3.5 \% \mathrm{NaCl}$ solution, no significant change occurred in the composition of $\mathrm{Ni}(\mathrm{OH})_{2}$ in the entire corrosion product layer, compared with the values before polarization. An $\mathrm{Al} 2 \mathrm{p}_{3 / 2}$ peak at $75.7 \mathrm{eV}$ was, therefore, attributed to the formation of $\mathrm{Al}(\mathrm{OH})_{3}$. Its composition was greatly increased, especially on the outer surface of the corrosion product layer. Surprisingly, the $\mathrm{Al}_{2} \mathrm{O}_{3}$ peak observed at $73.8 \mathrm{eV}$ before polarization, seemingly disappeared on the outer layer but greatly decreased in the inner layer. It may be reasoned that a particular transformation of the $\mathrm{Al}_{2} \mathrm{O}_{3}$ phases formed by the composite during immersion,occurs during polarization; such as a less hydrated $\mathrm{Al}_{2} \mathrm{O}_{3}$ with lower binding energy $(73.8 \mathrm{eV})$ being transformed into a more stable $\mathrm{Al}_{2} \mathrm{O}_{3} \cdot \mathrm{H}_{2} \mathrm{O}$ form with higher surface hydration $(74.5 \mathrm{eV})$. 

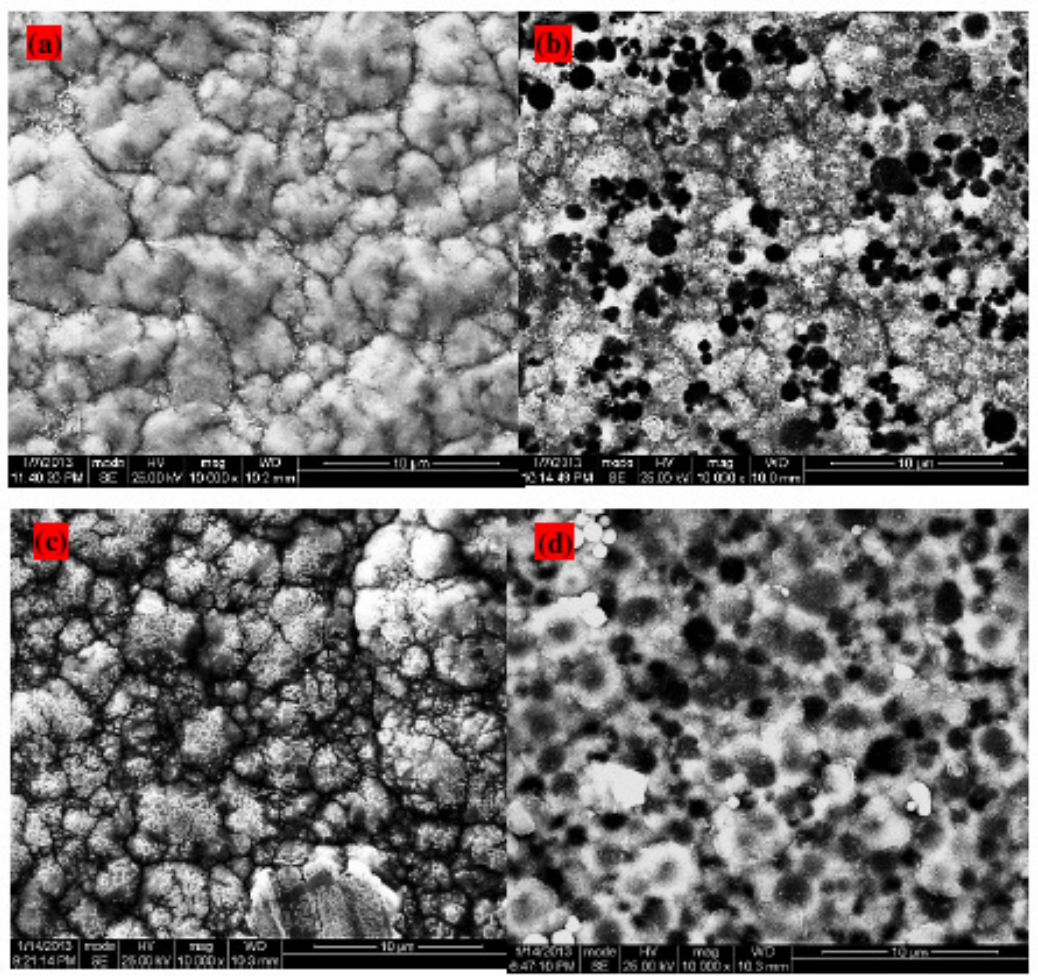

Figure 7. SEM surface micrographs after $72 \mathrm{~h}$ of immersion before polarization in $3.5 \%$ $\mathrm{NaCl}$ solution for (a) $\mathrm{Ni}$ and (b) $\mathrm{Ni}-28 \mathrm{wt} . \% \mathrm{Al}$ composite, and with subsequent polarization for (c) $\mathrm{Ni}$ and (d) $\mathrm{Ni}-28 \mathrm{wt}$. $\% \mathrm{Al}$ composite.

\section{Surface feature investigation}

In furtherance, SEM was employed to characterise the transformation of the surface microstructure of the Ni-28wt.\%Al composite, compared with the pure $\mathrm{Ni}$ coating, after $72 \mathrm{~h}$ immersion before and after polarization in $3.5 \% \mathrm{NaCl}$ solution. The comparison of the SEM surface morphologies of the pure $\mathrm{Ni}$ coating and the $\mathrm{Ni}-28 \mathrm{wt} . \% \mathrm{Al}$ composite after $72 \mathrm{~h}$ immersion before and after polarization in $3.5 \% \mathrm{NaCl}$ solution are given in Fig. 7. After $72 \mathrm{~h}$ immersion, before polarization in $3.5 \% \mathrm{NaCl}$ solution, corrosion products on the $\mathrm{Ni}$ coating appeared to form sparsely in the crevices between the large surface grains, Fig. 7(a), whereas a higher growth rate of corrosion products around the Ni grains occurred for the composite, Fig. 7(b). When polarized after $72 \mathrm{~h}$ immersion period, fine network-like Ni corrosion products occurred ubiquitously on the top of the pure Ni coating grains, but were no more clearly seen in the grooves among the large grains, Fig. 7(c). However, the corrosion product layer on the composite became denser, especially at the boundaries between the Ni grains and Al particles, and the Ni corrosion products covered the Al particles, Fig. 7(d). Lower magnification SEM surface morphologies of the coatings are presented in Fig. 8. Fig. 8(a) revealed that numerous pits occurred on the surface of the Ni coating, compared with the fewer pits on composite coating, Fig. 8(b). The magnified image of a pit on the Ni coating, Fig. 8(c), revealed that the pitting was deep enough to wear off the thickness of the coating and caused further corrosion of the underlying $\mathrm{Ni}$ substrate, which can easily be identified by the grinding marks made prior to electrodeposition. Conversely, the pits on the composite (morphology of one pit shown in Fig. 8 (d)) were much shallower and 
did not extend to the substrate, having a smoother surface which suggests the likelihood that a passive film would finally be re-formed in the pitting process.
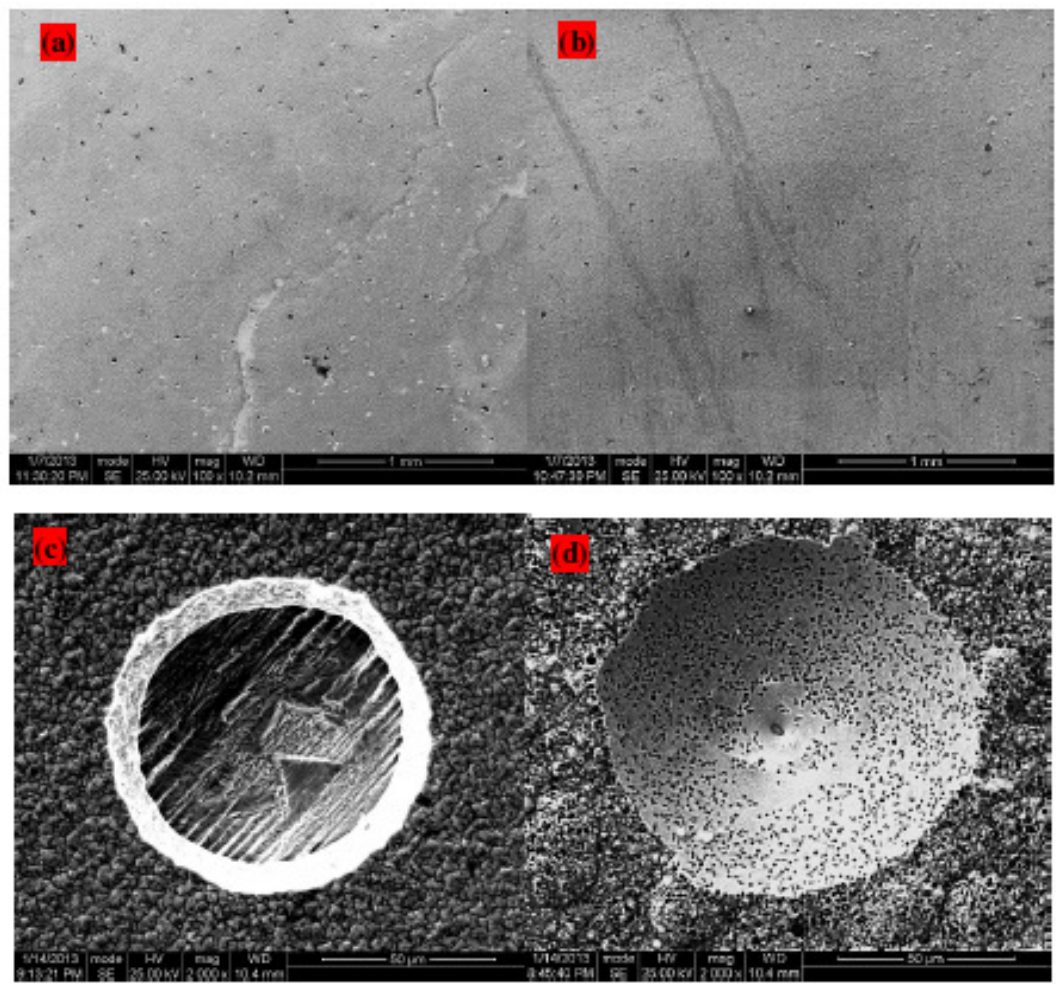

Figure 8. SEM surface micrographs after $72 \mathrm{~h}$ of immersion and subsequent polarization in $3.5 \% \mathrm{NaCl}$ solution showing pit morphologies on ((a), (c) Ni coating, and ((b), (d)) Ni-28wt.\% Al composite.

\section{Discussion}

The mechanism of the electrochemical corrosion behaviour of pure Ni coating involves the initial adsorption of water molecules on the coating surface, followed by the formation of a corrosion product layer composed of $\mathrm{Ni}(\mathrm{OH})_{2}$ and $\mathrm{NiO}$ which was the prominent cause of the anodic current density during the polarization of electrodeposited $\mathrm{Ni}$ coating in $3 \% \mathrm{NaCl}$ solution [1]. The saturation of the surface of the polarized $\mathrm{Ni}-28 \mathrm{wt} . \% \mathrm{Al}$ composite with adsorbed water molecules after $24 \mathrm{~h}$ immersion in $3.5 \% \mathrm{NaCl}$ solution, as confirmed by XPS characterization, is highly correlated with greatly refined microstructure and higher surface area of the Ni surface grains with Al particles reinforcement. This chemistry eventually increases the susceptibility (more negative $\mathrm{E}_{\mathrm{OCP}}$ ), and rate of the Ni grains in the composite to dissolution during the anodic polarization after $24 \mathrm{~h}$ immersion in $3.5 \% \mathrm{NaCl}$ solution. Although the $\mathrm{Al}$ particles can guarantee the formation of $\mathrm{Al}_{2} \mathrm{O}_{3}$, the $\mathrm{Al}_{2} \mathrm{O}_{3}$ composition is not enough to decrease the dissolution of the $\mathrm{Ni}$ grains; the electrochemical reaction occurs more rapidly around the $\mathrm{Ni}$ grains causing more $\mathrm{Ni}$ products to be formed, especially $\mathrm{Ni}(\mathrm{OH})_{2}$. The larger composition of $\mathrm{Ni}(\mathrm{OH})_{2}$ in the inner layer of the corrosion product layer, than on the outer layer, further shows the extent of water adsorption and penetration through the $\mathrm{Ni}-\mathrm{Al}$ composite coating. This is, therefore, the reason for higher rate of corrosion of the Ni-28wt.\% Al composite 
coating after $24 \mathrm{~h}$ immersion in $3.5 \% \mathrm{NaCl}$ solution, compared with the pure $\mathrm{Ni}$ coating.

When immersion time is increased up to $72 \mathrm{~h}$ in $3.5 \% \mathrm{NaCl}$ solution, there is a strong dehydration of the rapidly formed continuous layer of the $\mathrm{Ni}(\mathrm{OH})_{2}, \mathrm{ab}-$ initio enriching the corrosion product layer on the composite coating surface, according to the reaction (1) below.

\section{$\mathrm{Ni}(\mathrm{OH})_{2} \quad \longrightarrow \quad \mathrm{NiO}+\mathrm{H}_{2} \mathrm{O}$}

The XPS acquisition of $\mathrm{NiO}$ composition nearly double the $\mathrm{Ni}(\mathrm{OH})_{2}$ composition in the entire layer and the SEM surface feature of the composite after $72 \mathrm{~h}$ immersion before polarization in $3.5 \% \mathrm{NaCl}$ solution, Fig. 6, definitely supports this phenomenon. In contrast with the pure $\mathrm{Ni}$ coating, this rapid formation and dehydration of the $\mathrm{Ni}(\mathrm{OH})_{2}$ on the surface of the $\mathrm{Ni}-28 \mathrm{wt} . \% \mathrm{Al}$ composite coating is attributed to the high density of nucleation sites around the highly refined $\mathrm{Ni}$ surface grains in the composite. It is plausible that during this dehydration the increased penetration of air (oxygen), rather than water, through the corrosion product layer then triggers a more stable formation and enrichment of the $\mathrm{Ni}$ corrosion product layer with the highly developed and protective $\mathrm{Al}_{2} \mathrm{O}_{3}$. Compared with the pure $\mathrm{Ni}$ coating, it is this $\mathrm{Al}_{2} \mathrm{O}_{3}$ enrichment, especially in the inner layer at the corrosion product layer-substrate interface, that definitely increases the inertness of the composite coating surface, causing the more positive $\mathrm{E}_{\mathrm{OCP}}$ value and the greatly reduced anodic (and corrosion) current density during polarization after the $72 \mathrm{~h}$ immersion in $3.5 \% \mathrm{NaCl}$ solution.

During polarization after $72 \mathrm{~h}$ immersion in $3.5 \% \mathrm{NaCl}$ solution, the $\mathrm{Al}_{2} \mathrm{O}_{3}$ enrichment of the $\mathrm{Ni}$ corrosion product thickens the boundaries between the $\mathrm{Ni}$ grains and the Al particles in the composite coating, as evidenced by the SEM image in Fig. 6(d). This process further promotes oxidation half-reactions around the $\mathrm{Ni}$ grains converting them more into $\mathrm{NiO}$ and causing the increase in $\mathrm{NiO}$ composition after the polarization, rather than $\mathrm{Ni}(\mathrm{OH})_{2}$. In turn, the cathodic half-reactions plausibly occur around the $\mathrm{Al}$ particles and the formed $\mathrm{Al}_{2} \mathrm{O}_{3}$. Most prominent cathodic half-reactions in such neutral solution should involve the reduction of $\mathrm{Ni}^{2+}$ ions into $\mathrm{Ni}$ atoms, and of water molecules into $\mathrm{OH}^{-}$ions, around the $\mathrm{Al}$ particles and the formed $\mathrm{Al}_{2} \mathrm{O}_{3}$ during the cathodic scan. Based on XPS results, this increased $\mathrm{Ni}^{2+}$ reduction and $\mathrm{OH}^{-}$ion formation around the $\mathrm{Al}$ particles and the formed $\mathrm{Al}_{2} \mathrm{O}_{3}$ during the cathodic scan should, therefore, be the reason for: (i) the greatly increased $\mathrm{NiO}$ composition during anodic scan, (ii) the serious transformation of a 'more crystalline' $\mathrm{Al}_{2} \mathrm{O}_{3}$ at $73.8 \mathrm{eV}$ (richly formed during $72 \mathrm{~h}$ immersion) into a 'more hydrated' form at $74.7 \mathrm{eV}$ after polarization, and (iii) the subsequent increase in the $\mathrm{Al}(\mathrm{OH})_{3}$ composition, especially, on the outer layer of the corrosion product layer after polarization. The formation of a strongly hydrated $\mathrm{Al}_{2} \mathrm{O}_{3} \cdot \mathrm{H}_{2} \mathrm{O}$ was also reported during the characterization of the electrochemical corrosion behaviour of $\mathrm{Al}-\mathrm{Mn}$ composite coatings in $3.5 \% \mathrm{NaCl}$ solution [13]. Pitting corrosion is usually triggered by the chloride ions in the $3.5 \% \mathrm{NaCl}$ solution, adsorbing on and penetrating through the corrosion product layer and the $\mathrm{Ni}$ grain boundaries. While this is highly sustained (even attacking the substrate) for the pure $\mathrm{Ni}$ coating, the pitting process for the $\mathrm{Ni}-28 \mathrm{wt} . \% \mathrm{Al}$ 
composite coating is impeded once it reaches an $\mathrm{Al}_{2} \mathrm{O}_{3}$-rich front, especially in the inner layer of the $\mathrm{Ni}$ corrosion product where the $\mathrm{Al}_{2} \mathrm{O}_{3}$ assists in fortifying the corrosion product-substrate interface.

\section{Conclusions}

The characterization of the electrochemical corrosion behaviour of an electrodeposited $\mathrm{Ni}-28 \mathrm{wt} . \% \mathrm{Al}$ composite has been undertaken in $3.5 \% \mathrm{NaCl}$ solution, compared with pure $\mathrm{Ni}$ coating. The composite coating possesses greater surface area which initially increases the rates of adsorption of water, lowers the $\mathrm{E}_{\mathrm{OCP}}$ and, hence, the rate of electrochemical formation of $\mathrm{Ni}(\mathrm{OH})_{2}-$ enriched corrosion product layer, after $24 \mathrm{~h}$ immersion in $3.5 \% \mathrm{NaCl}$ solution. However, there is a rapid thickening of the corrosion product layer, with immersion time up to $72 \mathrm{~h}$, which facilitates the enrichment of the corrosion product layer with stable $\mathrm{Al}_{2} \mathrm{O}_{3}$ and leads to a greatly reduced corrosion rate, compared with the pure Ni coating.

\section{Acknowledgements}

B.I. Onyeachu is grateful to TWAS, the World Academy of Science and the Chinese Academy of Science (CAS) for the award of a CAS-TWAS Postgraduate Fellowship.

\section{References}

1. Li-Yuan Q, Jian-She L, Qing J. Effect of grain size on corrosion behaviour of electrodeposited bulk nanocrystalline Ni. Trans Nonferrous Met Soc China. 2010;82-89.

2. Shi L, Chufeng S, Gao P, et al. Mechanical properties and wear and corrosion resistance of electrodeposited $\mathrm{Ni}-\mathrm{Co} / \mathrm{SiC}$ nanocomposite coating. Appl Surf Sci. 2006;252:3591-3599.

3. Li J, Sun Y, Sun X, et al. Mechanical and corrosion-resistance performance of electrodeposited titania-nickel nanocomposite coatings. Surf Coat Technol. 2005;192:331-335.

4. Zimmerman AF, Palumbo G, Aust KT, et al. Mechanical properties of nickel silicon carbide nanocomposites. Mat Sci Eng A. 2002;328:137-146.

5. Hasannejad H, Shahrabi T, Jafarian M. Synthesis and properties of high corrosion resistant $\mathrm{Ni}$-cerium oxide nano-composite coating. Mater Corrosion. 2012;1-10.

6. Szczygiel B. Kolodziej M. Composite $\mathrm{Ni} / \mathrm{Al}_{2} \mathrm{O}_{3}$ coatings and their corrosion resistance. Electrochim Acta. 2005;4188-4195.

7. Feng $\mathrm{Q}, \mathrm{Li} \mathrm{T}$, Teng $\mathrm{H}$, et al. Investigation on the corrosion and oxidation resistance of $\mathrm{Ni}-\mathrm{Al}_{2} \mathrm{O}_{3}$ nano-composite coatings prepared by sediment codeposition. Surf Coat Technol. 2008;4137-4144.

8. Zhou Y, Peng X, Wang F. Oxidation of a novel electrodeposited Ni-Al nanocomposite film at $1050{ }^{\circ} \mathrm{C}$. Scripta Materialia. 2004;50:1429-1433. 
9. Peng $\mathrm{X}$, Li $\mathrm{M}$, Wang $\mathrm{F}$. A novel ultrafine-grained $\mathrm{Ni}_{3} \mathrm{Al}$ with increased cyclic oxidation resistance. Corrosion Sci. 2011;53:1616-1620.

10. Pourbaix M. Atlas of electrochemical equilibria in aqueous solutions. Houston, USA: NACE Cebelcor; 1974.

11. Natarajan R, Palaniswamy N, Natesan M. et al. XPS Analysis of Passive Film on Stainless Steel. Open Corrosion J. 2009;2:114-124.

12. Kim AY, Kim HS, Park N, et al. Low temperature synthesis of hexagonal shaped $\alpha-\mathrm{Al}_{2} \mathrm{O}_{3}$ using a solvothermal method. J Nanomater. 2012;1-7.

13. Zhang J, Zhang W, Yan $\mathrm{C}$, et al. Corrosion behaviours of $\mathrm{Zn} / \mathrm{Al}-\mathrm{Mn}$ alloy composite coatings deposited on magnesium alloy AZ31B (Mg-Al-Zn). Electrochim Acta. 2009;55:560-571. 